\title{
DILEMA PELAKSANAAN URUSAN PEMERINTAHAN UMUM DI KECAMATAN OLEH CAMAT \\ (Studi di Kecamatan Kahayan Tengah Kabupaten Pulang Pisau)
}

\author{
The Dilemma of Conducting Public Government Affairs in Sub-District by Camat \\ (Study in Central Kahayan District Of Pulang Pisau Regency)
}

\section{JHON RETEI ALFRI SANDI}

Universitas Palangka Raya, Kalimantan Tengah, Indonesia.

Email : jhonrete@fisip.upr.ac.id

\section{Keywords :}

Implementation

Government

Political Will

Intolerance

Diversity

Disintegration

\section{Kata Kunci :}

Pelaksanaan

Pemerintahan

Kemauan Politik

Intoleransi

Keberagaman

Disintegrasi

Published

October 2020

\begin{abstract}
Abstrak
Urusan pemerintahan umum memiliki urgensi penting ditengah keberagaman, ancaman intoleransi, radikalisme, disintegrasi bangsa saat ini. Peran kelembagaan Pusat di daerah baik berbasis keamanan dan ketertiban, pertahanan akan sulit berjalan secara optimal tanpa didukung struktur organisasi perangkat daerah dengan program kerjanya. Kendala regulasi, teknis dan political will pejabat dalam pengalokasi program kerja dan anggaran daerah ke unit organisasi terdepan seperti pemerintah kecamatan menjadi penyebab kurang terselenggara urusan pemerintahan umum dengan baik oleh Camat di kecamatan.

Penelitian ini berupaya mengkaji dilema penyelenggaraan urusan pemerintahan umum di Kecamatan Kahayan Tengah Kabupaten Pulang Pisau oleh camat, ditengah arus reformasi dan demokrasi yang memberi kewenangan luas kepada daerah kabupaten/kota serta Pemerintah Desa dengan undang-undang desa dan anggaran satu milyar desa melalui pendekatan diskriptif kualitatif.
\end{abstract}

\begin{abstract}
The affairs of public government have an important urgency amid diversity, the threat of intolerance, radicalism, the disintegration of the nation today. The central institutional role in the region is both security and order-based, defense will be difficult to run optimally without the support of the organizational structure of regional devices with its work program. Regulatory, technical and political constraints will be officials in the allocation of work programs and regional budgets to leading organizational units such as the sub-district government being the cause of the lack of public government affairs properly maintained by the District Court in the sub-district.

This research seeks to examine the dilemma of conducting public government affairs in The Central Kahayan District of Pulang Pisau Regency by the district, amid current reforms and democracy that gives broad authority to districts/ cities as well as village governments with village laws and budgets of one billion villages through a qualitative scripted approach.
\end{abstract}

\section{PENDAHULUAN}

Urusan Pemerintahan Umum adalah Urusan Pemerintahan yang menjadi kewenangan Presiden sebagai kepala pemerintahan yang mencakup 7 (tujuh) bidang yakni : (I) Pembinaan wawasan kebangsaan dan ketahanan nasional dalam rangka memantapkan pengamalan Pancasila, pelaksanaan Undang-Undang Dasar NKRI Tahun 1945, pelestarian Bhineka Tunggal
Ika serta mempertahankan dan memelihara keutuhan NKRI; (2) Pembinaan persatuan dan kesatuan bangsa; Pembinaan kerukunan antarsuku dan intrasuku, umat beragama, ras dan golongan lainnya guna mewujudkan stabilitas keamanan lokal, regional dan nasional; (3) Penanganan konflik sosial sesuai ketentuan peraturan perundang-undangan; (4) Koordinasi pelaksanaan tugas antar instansi pemerintahan yang ada di wilayah Daerah 
provinsi dan Daerah kabupaten/kota untuk menyelesaikan permasalahan yang timbul dengan memperhatikan prinsip demokrasi, hak asasi manusia, pemerataan, keadilan, keanekaragaman Daerah sesuai dengan ketentuan perundang-undangan; (5) Pengamalan kehidupan berdemokrasi berdasarkan Pancasila; (6) Pelaksanaan semua Urusan Pemerintahan yang bukan merupakan kewenangan Daerah dan tidak dilaksanakan oleh instansi vertikal.

Urusan Pemerintahan Umum ini dilaksanakan oleh Gubernur dan Bupati/Walikota di wilayah kerja masingmasing. Gubernur bertanggungjawab kepada Presiden melalui Menteri dan Bupati/Walikota bertanggungjawab kepada Menteri melalui Gubernur sebagai wakil Pemerintah Pusat. Untuk melaksanakan Urusan Pemerintahan Umum tersebut, Gubernur dan Bupati/Walikota dapat melimpahkan kepada Camat sebagaimana ditetapkan pada Pasal 25 ayat (6) UndangUndang Nomor 23 Tahun 2014 menyatakan :

"Bupati/walikota dalam melaksanakan urusan pemerintahan umum pada tingkat Kecamatan melimpahkan pelaksanaannya kepada Camat" ditingkat kecamatan dengan dibantu Instansi Vertikal tingkat Kecamatan dengan anggaran dari beban APBN (Pasal 25 ayat 5).

Guna menunjang kelancaran pelaksanaan Urusan

Pemerintahan Umum dimasing-masing tingkatan pemerintahan dibentuk Forkopimda provinsi, Forkopimda kabupaten/kota dan forum koordinasi pimpinan di Kecamatan sebagai wahana komunikasi dan koordinasi dalam rangka pelaksanaan.

Urusan Pemerintahan Umum memiliki urgensi besar dalam menjaga dan merawat bangunan Negara Kesatuan Republik Indonesia. Kuatnya arus globalisasi, demokratisasi, kemajuan teknologi informasi menjadi ancaman serius dan membutuhkan formulasi tepat agar NKRI tetap terjaga.

Dewasa ini perhatian terhadap pelaksanaan Urusan Pemerintahan Umum di daerah oleh pimpinan daerah dan pimpinan instansi teknis vertikal di daerah menjadi sangat penting. Berbagai tindakan kekerasan (radikalisme), sikap intoleransi bahkan aksi terorisme di tingkat bawah atau akar rumput (grassroot), di-idikasikan karena belum optimalnya pelaksanaan urusan pemerintahan umum di daerah oleh berpakai komponen perangkat Pemerintah termasuk perangkat pemerintah daerah seperti Camat dengan kewenangan yang diamanatkan pada undang-undang. Padahal masyarakat akar rumputlah (grassroot) yang menjadi arena sebaran sekaligus pembinaan yang rentan terpapar dengan berbagai paham in-toleransi.

Beberapa asumsi pemikiran terkait dengan eksistensi pelaksanaan atau implementasi tugas pemerintahan umum di daerah yang seyogianya harus dilaksanakan dengan baik dan serius oleh para pimpinan daerah dan pimpinan instansi vertikal di daerah termasuk Camat. Apakah para pejabat daerah telah meletakan proporsi implementasi segenap urusan pemerintahan baik urusan pemerintahan absulut, urusan pemerintahan konkuren dan urusan pemerintahan umum secara berimbang sehingga segenap urusan pemerintahan dapat dilaksanakan dengan baik di daerah? Apakah anggaran penyelenggaraan Urusan Pemerintahan Umum benar-benar tersedia sehingga memungkinkan aparatur pemerintah di daerah (camat) dapat melaksanakan tugas dan fungsinya dengan baik ?.

Pemerintah Kecamatan merupakan organisasi pemerintahan yang langsung berhadapan dengan masyarakat sebagai bagian organisasi pemerintahan yang wilayah kerja melingkupi pemerintah desa dan pemerintah kelurahan. Camat memiliki peranan strategis karena berhadapan dan bergaul langsung dengan kehidupan masyarakat desa/kelurahan yang berada di wilayah kerjanya, sehingga diyakini Camat memiliki pengetahuan, perhatian serta wawasan lebih luas dan komplek terhadap fenomena-fenomena yang dihadapi masyarakatnya, termasuk fenomena menyangkut kesadaran bersama dalam tatanan kehidupan berbangsa dan bernegara berdasarkan Pancasila, UUD 1945, NKRI dan Byineka Tunggal lka ditingkat akar rumput. 


\section{LANDASAN TEORI}

Sadu Wasistiono (1999) menyatakan bahwa pemerintah kecamatan memiliki karakteristik khusus dibanding tingkat pemerintahan lainnya. Ada karekteristik berbeda antara status perangkat daerah yang ada pada kecamatan dengan instansi/lembaga teknis daerah lainnya yang bersifat lebih spesifik. Dimana kewenangan Camat justru lebih bersifat umum dan menyangkut berbagai aspek dalam pemerintahan, pembangunan dan kemasyarakatan. Sehingga Camat memiliki tanggungjawab khusus untuk melaksanakan "tugas umum pemerintahan" sebagai kewenangan atributif. Kewenangan atributif adalah kewenangan yang melekat langsung pada Camat sebagaimana kedudukan, tugas dan fungsinya.

Camat memiliki tugas dan tanggungjawab menyelesaikan masalah-masalah yang dihadapi masyarakatnya William Dunn 2008 menyatakan : Masalah yang harus diatasi oleh Pemerintah adalah masalah publik yaitu nilai, kebutuhan atau peluang yang tak terwujudkan. Meskipun masalah tersebut dapat diidentifikasi tapi hanya mungkin dicapai lewat tindakan publik yaitu melalui kebijakan publik.

Kebijakan otonomi daerah sebagaimana dituang pada Undang-Undang No. 23 Tahun 2014 tentang Pemerintahan Daerah pada kenyataannya telah mendorong terjadi perubahan secara struktural, fungsional dan kultural dalam keseluruhan tatanan penyelenggaraan pemerintahan daerah. Salah satu perubahan yang sangat esensial adalah yang berkenaan dengan kedudukan,kewenangan, tugas dan fungsi Camat. Perubahan kedudukan kecamatan menjadi perangkat daerah kabupaten/kota dan camat menjadi pelaksana sebagian urusan pemerintahan yang menjadi wewenang Bupati/Walikota. Pergeseran kedudukan pemerintah kecamatan pertama-tama diatur pada Pasal I huruf m Undang-Undang Nomor 22 Tahun 1999 yang menyatakan : "Kecamatan merupakan wilayah kerja Camat sebagai Perangkat Daerah Kabupaten dan Daerah Kota". Pada Undang-Undang Nomor 32 Tahun 2004 sebagai revisi atas Undang-Undang Nomor 22 Tahun 1999 Pasal 120 ayat (2) kembali menyatakan bahwa : "Perangkat daerah kebupaten/kota terdiri atas sekretariat daerah, sekretariat DPRD, dinas daerah, lembaga teknis daerah, kecamatan dan kelurahan". Pada Undang-Undang Nomor 23 Tahun 2014 pengganti Undang-Undang Nomor 32 Tahun 2004 Pasal 209 ayat (2) menegaskan bahwa : "Perangkat daerah kabupaten terdiri atas sekretariat daerah, sekretariat DPRD, inspektorat, dinas, badan dan kecamatan".

Perubahan kedudukan kecamatan dan kedudukan camat membawa dampak pada kewenangan yang harus dijalanakan oleh Camat. Dampaknya menurut Sadu Wasistiono (2005) yakni : Kecamatan bukan lagi wilayah administrative pemerintahan dan dipersepsikan merupakan wilayah kekuasaan camat. Dengan paradigm baru, Kecamatan merupakan suatu wilayah kerja atau areal tempat Camat bekerja.

Camat adalah perangkat daerah kabupaten dan daerah kota dan bukan lagi kepala wilayah administrative pemerintahan, dengan demikian camat bukan lagi penguasa tunggal yang berfungsi sebagai administrator pemerintahan, pembangunan dan kemasyarakat, akan tetapi merupakan pelaksana sebagian wewenang yang dilimpahkan oleh Bupati/walikota.

$$
\text { Prof. Koeswara Kertapradja }
$$
menyatakan : Camat tidak lagi berkedudukan sebagai kepala wilayah kecamatan dan sebagai alat pemerintah pusat dalam menjalankan tugas-tugas dekonsentrasi, namun telah beralih menjadi perangkat daerah yang hanya memiliki sebagian kewenangan otonomi daerah dan penyelengaraan tugas-tugas umum pemerintahan dalam wilayah kecamatan.

Perubahan paradigmatik penyelenggaraan pemerintahan daerah tersebut, mengakibatkan pola distribusi kewenangan Camat menjadi sangat tergantung pada pendelegasian sebagian kewenangan pemerintahan dari Bupati/Walikota. Sebagai perangkat Daerah, Camat memiliki kewenangan delegatif, dimana kewenangan camat merupakan kewenangan yang dilimpahkan oleh 
Bupati/Walikota, sehingga luas atau terbatas kewenangan camat sangat bergantung dari kewenangan yang dilimpahkan oleh Bupati/Walikota atau didasarkan atas keinginan politis Bupati/Walikota.

Menurut Sadu Wasistiono (1999 : 33) ada karekteristik berbeda antara status perangkat daerah yang ada pada kecamatan dengan instansi/lembaga teknis daerah lainnya yang bersifat lebih spesifik. Dimana kewenangan Camat justru lebih bersifat umum dan menyangkut berbagai aspek dalam pemerintahan, pembangunan dan kemasyarakatan. Sehingga Camat memiliki tanggungjawab khusus untuk melaksanakan "tugas umum pemerintahan" sebagai kewenangan atributif. Kewenangan atributif adalah kewenangan yang melekat langsung pada Camat sebagaimana kedudukan, tugas dan fungsinya.

\section{PEMBAHASAN}

Pemerintah Kecamatan dengan Camat sebagai Kepala, memiliki kedudukan dan posisi strategis bagi terwujud tata kehidupan masyarakat yang demokratis di wilayah kerjanya. Camat hanya dapat melaksanakan tugas dan peran dengan baik manakala diberi kewenangan menyangkut wewenang urusan dan di dukung alokasi anggaran dari pemerintah kabupaten. Wewenang urusan dan dukungan anggaran tentu tidak hanya sebatas pada retorika politik atau ketentuan keputusan formal, tetapi lebih dari itu benar-benar dapat menempatkan Camat untuk mampu memberikan keputusan atau kebijakan sesuai harap masyarakat (publik interest) berpedoman pada ketentuan peraturan perundang-undangan.

Camat memiliki tugas dan tanggungjawab menyelesaikan masalah-masalah yang dihadapi masyarakatnya. Masalah yang harus diatasi cukup luas dan komplek yang menyangkut masalah-masalah publik. Camat sebagai pejabat pemerintah yang memberikan pelayanan di garda terdepan selain desa/kelurahan, relatif menghadapi persoalan yang komplek tidak hanya menyangkut masalah-masalah urusan formal atau prosedural belaka, tetapi juga menyangkut tata kehidupan sosial ekonomi, budaya masyarakat. Camat dituntut tidak hanya dapat menyelesaikan persoalanpersoalan kedinasan, tetapi juga persoalan tatanan kehidupan masyarakat sehari-hari seperti mengantar masyarakat yang sakit dan tidak mampu secara ekonomi, menampung dan memberikan tumpangan pada masyarakat yang tidak memiliki tempat tinggal dalam waktu sementara, bahkan juga terlibat mengurus orang menikah, orang mati, orang cerai, kawin lari dan lain-lain seperti diungkapkan Camat Kahayan Tengah :

"Pemerintah kecamatan sebagai unsur penyelenggaraan pemerintahan terdepan disamping pemerintah desa/kelurahan memiliki tugas dan tanggungjawab yang komplek, karena tuntutan pelayanan yang cukup komplek. Pelayanan kami I $x$ 24 jam, dari mengurus surat menyurat dikantor sampai mengurus orang melahir, meninggal, kawin lari, oranf sakit yang tidak mampu dan lain-lain diluar jam kantor.

Di kecamatan, Camat menjadi pigur sentral kepemimpin. Kehadiran Camat mampu memberi penguatan tidak hanya bagi para kepala desa dan perangkat desa di wilayah kerjanya tetapi juga bagi masyarakat seluruh kecamatan. Camat dipandang sebagai wakil pemerintah kabupaten atau pejabat wakil bupati atau utusan bupati, yang diharapkan dapat merespon serta menindaklanjuti kepentingan masyarakat seperti diungkapkan Camat Kahayan Tengah yakni :

"Masyarakat di Kecamatan sangat mengharapkan peranan Camat yang baik. Camat dipandang sebagai duta atau utusan Bupati yang diyakini mampu menjawab dan mengatasi permasalahanpermasalahan yang berkembang di kecamatan. Camat juga menjadi figur contoh dan teladan dalam memberikan pelayanan, sehingga keberadaan pelaksanaan tugas dan fungsi Camat tidak dibatasi oleh jam kerja, dan jenis urusan".

Berdasarkan kondisi diatas, sangat benar dikatakan

Prof. Sadu Wasistiono (2008) bahwa ada karekteristik berbeda antara status perangkat daerah yang ada pada kecamatan dengan instansi/lembaga teknis daerah lainnya yang bersifat lebih spesifik. Dimana kewenangan Camat justru lebih bersifat umum dan menyangkut 
berbagai aspek dalam pemerintahan, pembangunan dan kemasyarakatan.

Pada konteks Undang-Undang 23 Tahun 2014 tentang Pemerintahan Daerah Pasal 225 ayat (I), pemerintah kecamatan merupakan salah satu unsur Perangkat Daerah yang Camat dalam hal ini memiliki tugas yakni :

(I) menyelenggaraan urusan pemerintahan umum;

(2) mengkoordinasikan kegiatan pemberdayaan masyarakat;

(3) mengkoordinasikan upaya penyelenggaraan ketentraman dan ketertiban umum;

(4) mengkoordinasikan penerapan dan penegakan Perda dan Perkada;

(5) mengkoordinasikan pemeliharaan prasarana dan sarana pelayanan umum;

(6) mengkoordinasikan penyelenggaraan kegiatan pemerintahan yang dilakukan Perangkat Daerah di Kecamatan;

(7) membina dan mengawasi penyelenggaraan kegiatan Desa dan/atau kelurahan;

(8) melaksanakan urusan Pemerintahan yang menjadi kewenangan Daerah kabupaten/kota yang tidak dilaksanakan oleh unit kerja Perangkat Daerah kabupaten/kota yang ada di Kecamatan;

(9) melaksanakan tugas lain sesuai dengan ketentuan perundang-undangan

Tugas tersebut diatas merupakan tugas atributif yang menjadi tugas dan tanggungjawab penuh Pemerintah Kecamatan sebagai bagian Perangkat Pemerintah Daerah Otonom di bawah Bupati.

Pada ketentuan Pasal 25 ayat (2), (4) dan (5) melekat pula tugas dan tanggungjawab Pemerintah Kecamatan dalam melaksanakan tugas Urusan Pemerintahan Umum di Daerah yang menjadi tugas dan tanggungjawan kepala daerah (Bupati) sebagai wakil pemerintah Pusat di Daerah, melalui pelimpahan kewenangan dan pembiayaan bersumber dari APBN, manakala Bupati mendelegasikan kewenangan dan tanggungjawabnya kepada Camat. Tugas ini merupakan tugas delegatif dari Bupati kepada Camat.

Pemerintah Kecamatan Kahayan Tengah yang berkedudukan di Bukit Rawi mendapat amanat urusan dari Bupati Pulang Pisau menyangkut beberapa urusan kewenangan Bupati sebagai kepala pemerintah daerah otonom sebagaimana tercantum pada Peraturan Bupati Pulang Pisau No.II Tahun 2009. Urusan yang dilimpahkan bupati kepada camat melingkupi bidang pemerintahan, bidang ekonomi dan pertambangan, bidang pendidikan dan kesehatan, bidang sosial dan kesejahteraan masyarakat, bidang pertanahan, bidang perizinan tertentu sebagaimana tabel berikut :

Tabel I. Urusan Yang Dilimpahkan Bupati Kepada Camat di Kabupaten Pulang Pisau Berdasarkan Peraturan Bupati Pulang Pisau No. II Tahun 2009

A. Bidang Pemerintahan

I. Pembinaan idiologi negara dan kesatuan bangsa.

2. Mengkoordinasikan upaya penyelenggaraan ketentraman dan ketertiban masyarakat.

3. Pelaksanaan koordinasi dan pembinaan Kesatuan Polisi Pamong Praja dan Perlindungan Masyarakat (LINMAS) di wilayah kerjanya.

4. Memfasilitasi kerukunan hidup antar umat beragama.

5. Memimpin penyelenggaraan kegiatan pemerintahan di tingkat kecamatan.

6. Pengkoordinasian kegiatan UPTD/instansi pemerintahan di wilayah kerjanya.

7. Membina penyelenggaraan pemerintahan desa dan kelurahan.

8. Melakukan penilaian atas laporan pertanggungjawaban kepala desa dan kelurahan.

9. Memfasilitasi penyelenggaraan kerjasama antar kelurahan dan penyelesaian atas perselisihan antara desa dan kelurahan, antar kelompok dalam wilayah kerjanya.

10. Menyelenggarakan lomba/penilaian desa dan kelurahan tingkat desa/kelurahan.

II. Pelaksanaan administrasi kependudukan dan catatan sipil :

a. Penandatanganan Kartu Keluarga

b. Penandatanganan Surat Keterangan Ahli Waris. 


\begin{tabular}{|c|c|}
\hline & $\begin{array}{l}\text { c. Penandatanganan Surat Keterangan } \\
\text { Pindah WNI. } \\
\text { d. Penandatanganan Surat Keterangan } \\
\text { Cerai. } \\
\text { e. Penandatanganan Surat Bepergian } \\
\text { Haji. } \\
\text { f. Penandatanganan Surat Keterangan } \\
\text { Dispensasi untuk Menikah Bagi } \\
\text { Warga Muslim. } \\
\text { 12. Pembinaan Forum RT/RW tingkat } \\
\text { kecamatan. } \\
\text { 13. Pembinaan organisasi RT/RW diwilayah } \\
\text { kerjanya. } \\
\text { 14. Memfasilitasi kegiatan pembentukan, } \\
\text { penghapusan, penggabungan } \\
\text { desa/kelurahan. } \\
\text { 15. Pengusulan pengangkatan dan mutasi } \\
\text { perangkat desa } \\
\text { 16. Pembinaan kepegawaian : } \\
\text { a. Teguran lisan } \\
\text { b. Teguran tertulis } \\
\text { c. Pernyataan tidak puas. } \\
\text { 17. Perawatan dan pemeliharaan barang } \\
\text { pemerintah kecamatan dan barang } \\
\text { pemerintah/pemerintah daerah di desa } \\
\text { dan kelurahan. } \\
\text { 18. Membantu pelaksanaan Pemilu } \\
\text { Legislatif, Pemilu Persiden dan Wakil } \\
\text { Presiden dan Pemilihan Kepala Daerah } \\
\text { yang demokratis, langsung umum, } \\
\text { bebas, rahasia, jujur, adil dan beradab. } \\
\text { 19. Penegakan dan pelaksanaan peraturan } \\
\text { daerah dan keputusan kepala daerah } \\
\text { serta peraturan perundang-undangan } \\
\text { lainnya di wilayah kerjanya. }\end{array}$ \\
\hline B. & $\begin{array}{l}\text { Bidang Ekonomi dan Pertambangan } \\
\text { 1. Memfasilitasi dan mengkoordinasikan } \\
\text { penyelenggaraan kegiatan pembangunan } \\
\text { di wilayah kerjannya. } \\
\text { 2. Memfasilitasi kegiatan pengembangan } \\
\text { perekonomian desa dan kelurahan. } \\
\text { 3. Membantu dan melakukan pengawasan } \\
\text { serta pelaporan langkah-langkah } \\
\text { penanggulangan terjadinya pencemaran } \\
\text { dan kerusakan lingkungan. } \\
\text { 4. Membantu memfasilitasi pembinaan dan } \\
\text { pengembangan serta pemantauan } \\
\text { kegiatan perindustrian, perdagangan, } \\
\text { pertambangan, kepariwisataan, } \\
\text { perkoperasian usaha kecil menengah } \\
\text { (UKM) dan golongan ekonomi lemah, } \\
\text { peternakan, pertanian, perkebunan dan } \\
\text { perikanan. } \\
\text { 5embantu pengawasan atas } \\
\text { pengambilan sumberdaya alam (SDA } \\
\text { tanpa ijin dan dapat mengganggu serta } \\
\text { membahayakan lingkungan hidup. } \\
\text { 6embantu memfasilitasi penerbitan } \\
\text { pedagang kaki lima (PKL) }\end{array}$ \\
\hline
\end{tabular}

7. Pengkoordinasian pelaksanaan pembangunan swadaya masyarakat.

8. Memfasilitasi koordinasi penyusunan perencanaan pembangunan desa dan kelurahan;

9. Melakukan pengawasan pasar tradisional.

10. Pemberdayaan kelembagaan petani dalam rangka ketahanan pangan masyarakat.

II. Memfasilitasi pembenahan dan pemberdayaan perkumpulan petani pemakai air (P3A)/perkumpulan petani pemakai air tanah (P3AT).

12. Membantu pengawasan terhadap pengadaan, peredaran, penggunaan pestisida dan herbisida.

13. Pemantauan dan pemanfaatan sumberd air dan irigasi.

14. Pembinaan tenaga petugas penyuluh lapangan (PPL) pertanian.

15. Membantu pengawasan dan pengendalian kegiatan pertambangan.

C. Bidang Pendidikan dan Kesehatan

I. Membantu pembinaan dan pengawasan kegiatan program pendidikan, generasi muda, keolahragaan, kebudayaan, kepramukaan serta peranan wanita.

2. Memfasilitasi pembinaan dan pengawasan kegiatan program kesehatan masyarakat.

3. Memfasilitasi penyelenggaraan kegiatan keluarga berencana dan kesehatan masyarakat.

4. Memfasilitasi pelaksanaan penyuluhan program wajib belajar.

D. Bidang Sosial dan Kesejahteraan Rakyat

I. Pembinaan kegiatan pemberdayaan masyarakat.

2. Memfasilitasi pembinaan dan pengawasan kegiatan program kesehatan masyarakat.

3. Memfasilitasi kegiatan penanggulangan masalah sosial.

4. Melaksanakan penyaluran santunan kematian.

5. Membantu pelaksanaan bantuan korban banjir.

6. Membantu pelaksanaan kebijakan/program bidang sosial dan kesejahteraan rakyat.

7. Membantu pelaksanaan kesuksesan program pembangunan keluarga sejahtera dan pemberdayaan perempuan.

E. Bidang Pertanahan

I. Membantu pengawasan atas tanah-tanah negara dan asset pemerintah daerah diwilayah kerjanya.

2. Memfasilitasi pelaksanaan pembebasan tanah milik dan pelepasan hak yang dibiayai oleh APBD/APBN yang akan 


\begin{tabular}{|c|c|}
\hline & $\begin{array}{l}\text { digunakan untuk kepentingan } \\
\text { pembangunan, serta peralihan status } \\
\text { tanah dari tanah negara menjadi hak } \\
\text { milik sesuai dengan ketentuan peraturan } \\
\text { perundang-undangan. } \\
\text { 3. Pembinaan dan pengawasan tentang } \\
\text { penggunaan alkah/kuburan yang dikelola } \\
\text { oleh masyarakat. } \\
\text { 4. Membantu dalam hal penetapan } \\
\text { peruntukan, proses pengalihan dan } \\
\text { perubahan status tanah. } \\
\text { 5. Pelaksanaan monitoring dan inventarisasi } \\
\text { terhadap setiap kegiatan yang berkaitan } \\
\text { dengan penggunaan tanah terlantar dan } \\
\text { tanag negara bebas di wilayah kerjannya. } \\
\text { 6. Memberikan rekomendasi lahan untuk } \\
\text { lokasi transmigrasi. } \\
\text { 7. Memfasilitasi usaha penyelesaian } \\
\text { sangketa/perselisihan masalah tanah } \\
\text { secara musyawarah di tingkat kelurahan. }\end{array}$ \\
\hline F. & 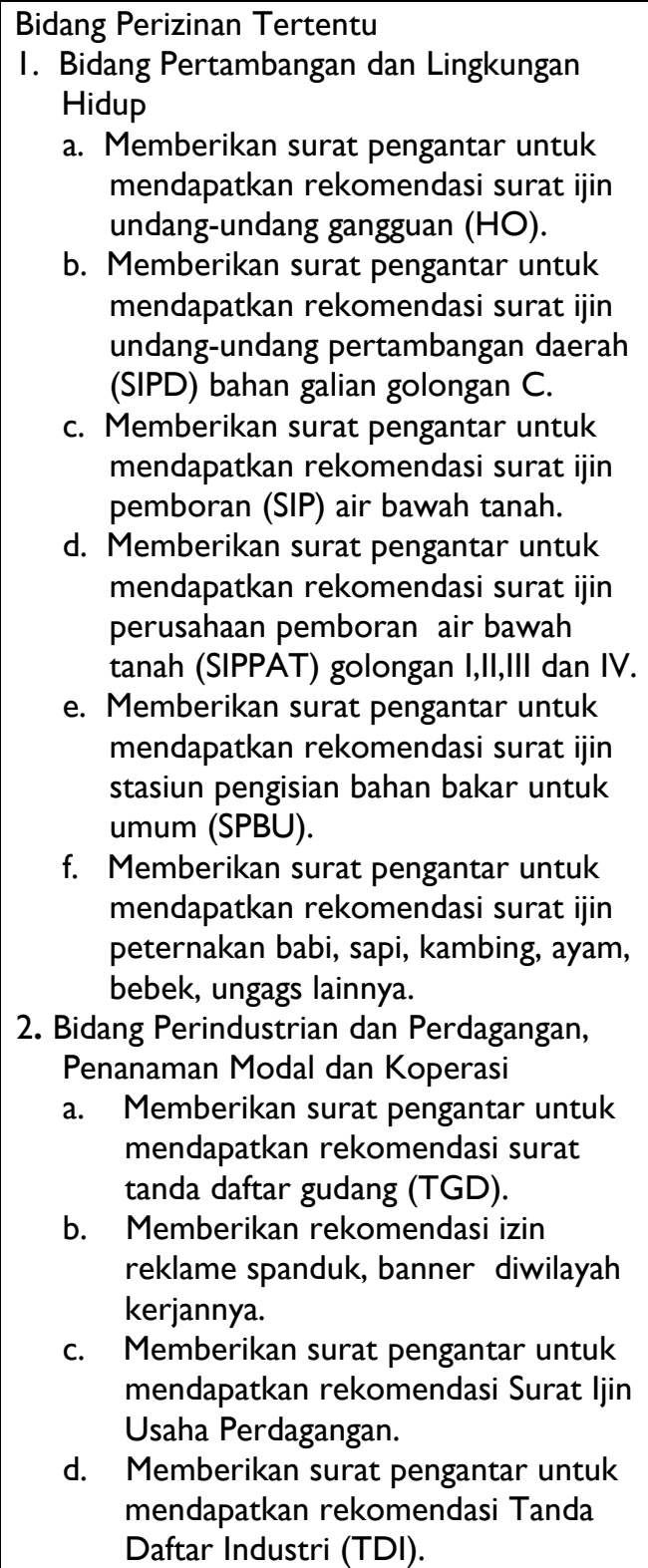 \\
\hline
\end{tabular}

e. Memberikan surat pengantar untuk mendapatkan rekomendasi Tanda Daftar Perusahaan (TDP).

f. Memberikan surat pengantar untuk mendapatkan rekomendasi penerbitan surat ijin tempat usaha (SITU) dan surat pemberitahuan surat usaha.

g. Memberikan surat pengantar untuk mendapatkan rekomendasi penerbitan ijin reklame papan nama toko.

h. Memberikan surat keterangan usaha.

i. Memberikan surat pengantar untuk mendapatkan rekomendasi registrasi atas :

I. Permohonan industri kecil rumah tangga dan kerajinan dengan skala industri dibawah Rp.5.000.000.

2. Usaha dagang kecil dengan skala omset penjualan dibawah Rp.25.000.000.

3. Bidang Pertanahan

a. Memberikan surat pengantar untuk mendapatkan rekomendasi pengadaan tanah bagi pelaksanaan pembangunan untuk kepentingan umum.

b. Memberikan surat pengantar untuk mendapatkan rekomendasi ijin peralihan/pemindahan hak atas tanah.

c. Memberikan surat pengantar untuk mendapatkan rekomendasi ijin perubahan penggunaan ha katas tanah.

d. Memberikan surat pengantar untuk rekomendasi penentuan atas hak tanah.

e. Penerbitan surat keterangan tanah.

\section{Bidang Pariwisata}

Menerbitkan surat pengantar untuk mendapatkan rekomendasi ijin keramaian yang bersifat incidental :

a. Mainan anak-anak (komedi putar dII).

b. Pasar malam

\section{Bidang Permukiman}

Memberikan rekomendasi izin mendirikan menambah bangunan (IMMB) atas :

a. Bangunan rumah tempat tinggal non komersil, termasuk pagar dan saluran di depan sekitar rumah, tidak termasuk IMB bagi perumahan yang dilaksanakan oleh pengembang perumahan.

b. Bangunan rumah sewa, kost, pondokan dan bangunan sejenisnya.

c. Warung kios, depot dan lain-lain bangunan sejenisnya dengan luas sampai dengan atau kurang dari 20 $\mathrm{m} 2$. 


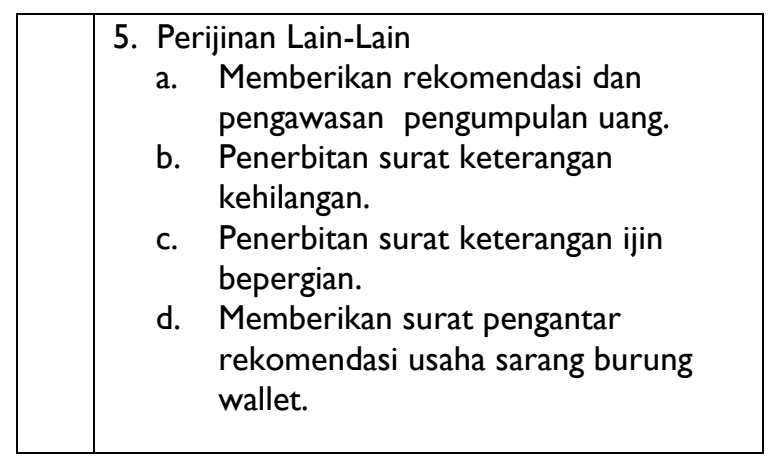

Urusan wewenang bupati yang dilimpahkan kepada camat Kahayan Tengah relative cukup luas dan melingkupi hampir semua bidang pelayanan pemerintah daerah yang melekat baik urusan atributif sebagaimana ketentuan Pasal 225 ayat (2), (4) dan (5) dan urusan delegatif sebagaimana ketentuan Pasal 25 ayat (4).

Delegasi wewenang urusan Bupati kepada Camat melingkupi pelaksanaan tugas dan fungsi Bupati sebagai kepala daerah otonom yang di dalam urusan tersebut juga terkait langsung dengan kewajiban dan tanggungjawan pelaksanaan Urusan Pemerintahan Umum di Kecamatan seperti :

- Bidang Pemerintahan menyangkut pembinaan ideologi, mengkoordinasikan upaya penyelenggaraan ketentraman dan ketertiban masyarakat, Memfasilitasi kerukunan hidup antar umat beragama, Memfasilitasi penyelenggaraan kerjasama antar kelurahan dan penyelesaian atas perselisihan antara desa dan kelurahan, antar kelompok dalam wilayah kerjanya.

- Bidang Sosial dan Pertambangan Memfasilitasi kegiatan penanggulangan masalah sosial.

Pelaksanaan Urusan Pemerintahan Umum di Kecamatan, dipandang sebagai bagian pelaksanaan tugas Camat sebagai perangkat daerah otonom, sehingga alokasi anggaran kegiatan menjadi satu kesatuan dengan anggaran unit organisasi perangkat daerah kabupaten yang tertuang pada DPA Kecamatan seperti diungkapkan Camat Kahayan Tengah Leting,S,Sos :

Bupati Pulang Pisau tidak secara khusus menetapkan pelimpahan urusan menyangkut Urusan Pemerintahan Umum di Daerah Kecamatan kepada
Camat. Bupati hanya menetapkan Surat Pelimpahan melalui Peraturan Bupati No. II Tahun 2016. Pelaksanaan Urusan Pemerintahan Umum dipandang sebagai bagian pelaksanaan urusan pemerintah kecamatan sebagai unit organisasi pemerintah daerah otonom.

Berikat skema pola pelaksanaan Urusan Pemerintahan Umum di Kecamatan :

Gambar I. Pola Pelimpahan Kewenangan Bupati Pulang Pisau terkait Urusan Atributif dan Delegatif kepada Camat Kahayan Tengah.

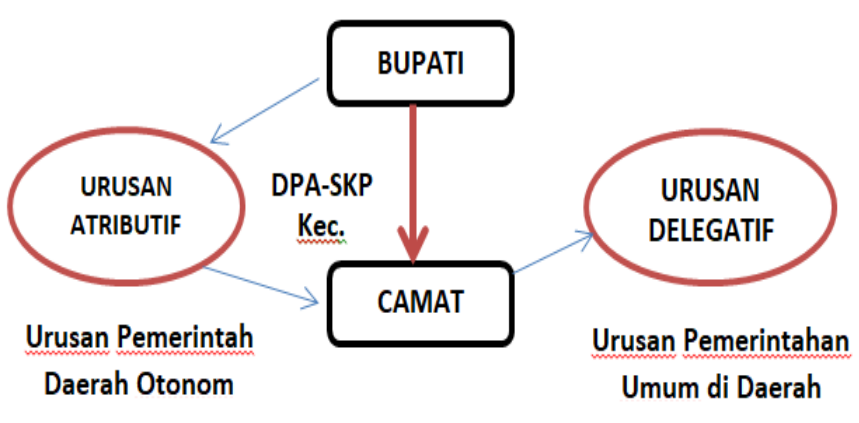

Meskipun Bupati secara khusus tidak melimpahkan kewenangan pelaksanaan pemerintahan umum di kecamatan, akan tetapi pelaksanaan Urusan Pemerintahan Umum harus dilaksanakan oleh Camat selaku pempinan wilayah kecamatan. Pihak Kecamatan dalam pelaksanaan tugas yang dibebankan harus ditopang pula dengan anggaran yang memadai. Akan tetapi pada kenyataannya, urusan yang cukup komplek diserahkan kepada Camat tidak disertai dengan dukungan anggaran yang memadai. Akibatnya Camat kurang optimal dalam melaksanakan segenap urusan baik bersifat urusan atributif maupun urusan delegatif yang menjadi tugas dan tanggungjawabnya.

Alokasi anggaran pemerintah kabupaten kepada perangkat daerah kecamatan yang sangat minim baik untuk kegiatan atau program Belanja Langsung (Modal) dan Belanja Tidak Langsung (Rutin) tentu berdampak pada kualitas kerja pemerintah kecamatan sebagaimana ditunjukan pada tabel. 
Tabel 2. Alokasi Anggaran Pemerintah Kecamatan Kahayan Tengah 2015, 2016-2018

\begin{tabular}{|c|c|c|c|c|}
\hline \multirow{2}{*}{ Thn } & \multicolumn{4}{|c|}{ Anggaran } \\
\cline { 2 - 5 } & BTL & BL & Total & Realisasi \\
\hline 2014 & 1.280 .391 .004 & 406.000 .000 & 1.686 .391 .004 & 1.563 .171 .987 \\
\hline 2016 & 1.280 .391 .004 & 406.000 .000 & 1.686 .391 .004 & 1.563 .171 .987 \\
\hline 2017 & 1.588 .758 .614 & 727.700 .000 & 2.194 .758 .614 & - \\
\hline 2018 & 1.588 .758 .614 & 728.000 .000 & 2.316 .758 .614 & - \\
\hline
\end{tabular}

Sumber : Data Olahan (LPPD Kab. Pulang Pisau).

Anggaran ini tentu jauh dari tingkat bebankan kerja yang diserahkan serta kapasitas dalam merespon dan menindaklanjuti harapan, keinginan yang komplek dari masyarakat sebagaimana yang menjadi tuntutan dan aspirasi 14 desa/kelurahan dan penduduk sebanyak 7.698 diwilayah Kecamatan Kahayan Tegah.

Pemerintah kecamatan, dengan kondisi anggaran yang belum optimal berupaya mengatur dan mengelola anggaran sebagaimana yang ditetapkan pada DPA -SKP Kecamatan. Camat berdaya upaya melaksanakan penyelenggaraan kegiatan pemerintahan, pembangunan dan pembinaan sosial kemasyarakat dengan baik, meskipun pada realitas banyak terdapat tuntutan dan aspirasi masyarakat kecamatan yang tidak bisa dipenuhi dan banyak tugas pokok yang tidak dapat terselenggara dengan baik karena situasi dan kondisi yang dihadapi pemerintah kecamatan.

Camat dengan segenap jajaran merencanakan dan melaksanakan program kerja dengan mengacu pada kebutuhan masyarakat, kemampuan anggaran yang tersedia serta skala prioritas pembangunan kecamatan.

Kebijakan yang dilakukan Camat dengan memprioritas anggaran kepada pembiayaan belanja rutin kantor seperti : beban listrik, honor tenaga kontrak, rapat dan perjalanan dinas. Sedangkan kegiatan belanja program disusun dengan memperhatikan sisa serapan dana rutin. Tidak banyak kegiatan yang dapat diakomodir berdasarkan alokasi anggaran tersebut seperti disampaikan Camat Kahayan Tengah :
“Program kegiatan pembangunan atau belanja modal disusun oleh Pemerintah Kecamatan dengan memperhatikan alokasi anggaran dengan serapan nilai beban belanja rutin terlebih dahulu. Rata-rata belanja modal yang mampu terbiaya setiap tahun seperti tahun 2016 sampai 2018 hanya berkisar antara 400 juta - 700 juta lebih sedikit. Kecamatan tidak mungkin dapat membuat program yang aspiratif manakala jumlah alokasi anggaran pembangunan sebagaimana ditetapkan pada DPASKP Kecamatan Kahayan Hilir hanya 700 juta. Anggaran kecamatan ini sangat kecil dibandingkan anggaran yang dikelola pemerintah desa yang ratarata lebih dari I milyar per tahun.

Minim anggaran berdampak pada kurang responsive program kerja pemerintah kecamatan. Pelaksanaan tugas pemerintah kecamatan dilakukan hanya sebisanya oleh Camat, atau dengan bahasa lain “ala kadar", sehingga hakikat adanya Pemerintah yang melayani dan responsive menjadi jauh dari kenyataan. Pemerintah kecamatan tidak mampu melaksanakan urusan pemerintahan atributif dengan baik, lebih-lebih urusan delegatif.

Delegasi terkait pelaksanaan Urusan Pemerintah Umum di Kecamatan oleh Bupati Pulang Pisau kepada Camat memang masih belum dilakukan. Bupati hanya memberikan delegasi kewenangan menyangkut beberapa urusan pemerintahan, ekonomi dan pertambangan, bidang sosial dan kesejahteraan masyarakat, perizinan, rekomendasi atau penerbitan surat-keterangan dan lain-lain. Kewenangan Urusan pemerintahan kecamatan lebih bersumber atau mengacu pada ketentuan Pasal 225 ayat ayat (I) atau sebagai urusan atributif perangkat daerah otonom.

Pemerintah Kecamatan Kayahan Tengah relatif mengalami kesulitan melaksanakan Urusan Pemerintahan Umum di Kecamatan, termasuk pula Urusan Pemerintahan Otonom karena anggaran yang terbatas tersebut. Pemerintah kecamatan relatif kurang optimal melakukan koordinasi, komunikasi dan sinkronisasi berbagai program kegiatan di semua desa/kelurahan karena keterbatasan pembinaan yang dilakukan serta menguatnya peranan pemerintah desa dengan berlakunya Undang-Undang No. 6 Tahun 2014 
tentang Desa dan dialokasikan anggaran desa dalam bentuk Dana Desa (DD) sebesar I milyar.

Undang-Undang No. 23 Tahun 2014 tentang Pemerintahan Daerah Pasal 22I telah menetapkan bahwa pembentukan Kecamatan adalah dalam rangka meningkatkan koordinasi penyelenggaraan pemerintahan, pelayanan publik, dan pemberdayaan masyarakat Desa/kelurahan.

Bagaimana mungkin Pemerintah Kecamatan mampu melaksanakan koordinasi dengan baik manakala, pembiayaan kegiatan pemerintah kecamatan hanya mampu membiayai kegiatan-kegiatan rutin operasional kantor.

Pemerintah Kecamatan Kahayan Tengah dalam penyelengggaraan Urusan Pemerintahan Umum di wilayah kecamatan, menyiasati dengan bertumpu pada program-program kerja yang diselenggarakan pemerintah Kabupaten Pulang Pisau, khususnya Badan Kesatuan Bangsa dan Politik Kabupaten, instansi pemerintah daerah otonom lainnya seperti Dinas Sosial Kabupaten, Satuan Polisi Pamong Praja Kabupaten, Badan Penanggulangan Bencana dan lainlain.

Progam kerja juga diharapkan datang dari Instansi Vertikal tingkat kabupaten atau kecamatan seperti Koramil, Polsek serta kelembagaan kemasyarakatan yang berperan menjadi mitra kerja pemerintah kecamata. Menurut Camat Kahayan Tengah, Leting, S.Sos, Unsur Forkopimda kecamatan baik Koramil dan Polsek sangat memberikan dukungan bagi terselenggaranya kegiatan urusan yang menjadi tanggungjawab pemerintah kecamatan, termasuk Urusan Pemerintahan Umum.

Koramil selaku unsur teknis pemerintahan yang bertanggungjawab menjamin terciptanya pertahanan dan Polsek yang berwenang menciptakan keamana dan ketertiban dalam masyarakat kecamatan Kahayan Tengah memiliki andil besar bagi terbangunnya kondisi keamanan dan ketertiban yang mantap di kecamatan Kahayan Tengah selama ini.
Dalam pelaksanaan tugas sehari-hari unsurunsur Forkopimda selalu melaksanakan koordinasi, sehingga program-program kerja yang direncanakan oleh masing-masing institusi dapat berjalan dengan baik. Menurut Camat Kahayan Tengah Leting,S.Sos koordinasi dengan Instansi Vertikal di daerah kecamatan relative berjalan dengan baik. Kapolsek atau pun Danramil selalu melakukan komunikasi dengan baik ke pemerintah kecamatan.

Badan Kesatuan Bangsa dan Politik Pulang Pisau sebagaimana Tugas dan Fungsi yang diatur pada Peraturan Bupati Pulang Pisau No.3I Tahun 2016 tentang Pembentukan dan Susunan Perangkat Daerah Kota Palangka Raya memiliki tugas melaksanakan, penyusunan dan pelaksanaan kebijakan serta membantu Kepala Daerah dalam penyelenggaraan Pemerintah bidang Kesatuan Bangsa dan Politik, melakukan pembinaan teknis dan pengkoordinasian serta mediasi/fasilitasi, perumusan standar, norma, pedoman, kriteria dan prosedur teknis serta pelaksanaan nilai-nilai kebangsaan, pembauran, kewaspadaan nasional, fasilitasi organisasi kemasyarakatan dan organisasi politik serta melaksanakan tugas pembinaan terkait urusan kepentingan nasional dibidang idiologi, pembinaan kebangsaan, politik, persatuan dan kesatuan, pengamalan Pancasila dan UUD 1945, melakukan tugastugas tersebut diseluruh wilayah kabupaten Pulang Pisau. Pelaksanaan tugas tersebut dilaksanakan sendiri oleh Badan Kesbangpol Kabupaten dengan dan atau tanpa melibatkan pemerintah kecamatan. Kegiatan program kerja dapat dilaksanakan di ibukota kabupaten Pulang Pisau dan bisa pula dilaksanakan di wilayahwilayah kecamatan dengan menjalin kerjasama pelaksanaan dengan pemerintah kecamatan (lazimnya : pemerintah kecamatan menyediakan tempat kegiatan dan peserta, sementara nara sumber dan seluruh pembiayaan menjadi beban Badan Kesatuan Bangsa dan Politk Kabupaten Pulang Pisau). 
Menurut Camat Kahayan Tengah :

"Sebenarnya kegiatan-kegiatan yang dilaksanakan pihak Kesbangpol Kabupaten yang bersifat sosialisasi atau penyuluhan dapat saja dilimpahkan pelaksanaaan ke kecamatan. Pihak kecamatan pasti mampu melaksanakan dengan didampingi oleh Pemerintah Kabupaten. Namun sampai saat ini hampir semua kegiatan masih terpusat di dinas/badan kabupaten, sementara kecamatan dengan anggaran yang terbatas tidak mampu melaksanakan atau membuat program yang baik dan menjawab kebutuhan banyak masyarakat".

Pelaksanaan Urusan Pemerintahan Umum di Kecamatan oleh Pemerintah Kabupaten Pulang Pisau, lebih bertumpu pada Perangkat Daerah (PD) Kabupaten (PD) kabupaten lainnya seperti Badan Kesatuan Bangsa dan Politik, Dinas Sosial dan lain-lain.

Pemerintah Kecamatan hanya dijadikan obyek lokasi kegiatan, yang keberadaan bisa dilibatkan atau tidak dilibatkan. Hal ini berdampak pada beberapa pelaksanaan program fisik maupun non fisik yang tidak diketahui pelaksanaan di kecamatan oleh Pemerintah Kecamatan, termasuk pelaksanaan program urusan pemerintahan umum di kecamatan. Pemerintah kecamatan kadang-kadang hanya mengetahui keberadaan kegiatan tersebut setelah proyek atau program selesai pelaksanaan. Pada sisi lain Pemerintah Kecamatan pun menjadi semakin jauh dengan masyarakat di wilayah kecamatannya, karena kuantitas interaksi dan komunikasi yang minim, sehingga peran keberadaan pemerintah kecamatan pun menjadi alat melengkapi struktur organisasi sebagaimana diatur dalam peraturan perundangan-undangan. Bukan semestinya secara secara fungsional dapat memberikan kontribusi optimal bagi keberhasilan pelaksanaan pemerintahan dan pelayanan publik atau sebagai entri point untuk mewujudkan Good Governance sebagaimana yang menjadi tuntutan pemerintahan modern di era revolusi industri 4.0. Berikut pola pelaksanaan Urusan Pemerintahan Umum di Kecamatan pada Kabupaten Pulang Pisau :
Gambar 2. Pola Pelaksanaan Urusan Pemerintahan Umum di Kabupaten Pulang Piasau. Pola Pelaksanaan Urusan Pemerintah Umum di Kabupaten Pulang Pisau

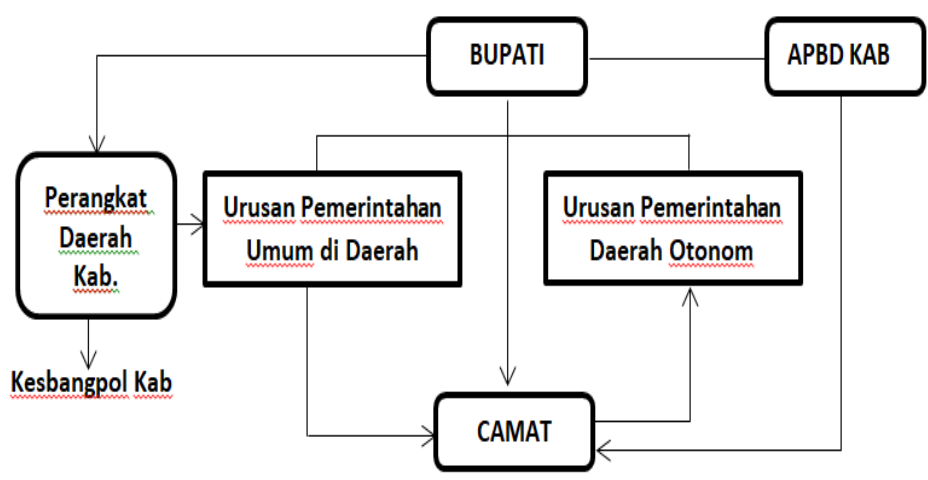

Pola delegasi kewenangan seperti ini tentu kurang memberdayakan pemerintahan tingkat bawah. Padahal pemerintah kecamatan merupakan salah satu unsur penyelenggara pemerintahan terdepan, yang memiliki kedekatan langsung dengan masyarakat.

Pemerintah Kabupaten seharusnya memandang bahwa : Sebagai organisasi pemerintahan terdepan di tingkat daerah kabupaten dengan sejumlah kewenangan atributif dan delegatifnya, Pemerintah Kecamatan Kahayan Tengah harus diperkuat secara formal dan aktual. Tidak hanya dengan "cek kosong" Peraturan Bupati tentang 'Delegasi Kewenangan Belaka", tetapi juga "political will” para pejabat daerah kabupaten dalam memberdayakan dan memfungsikan keberadaan pemerintah kecamatan.

Pemerintah desa dan kecamatan harus dijadikan basis atau tiang tumpu pelayanan publik. Kerena berbagai persoalan publik, termasuk gejala krisis kebangsaan, intoleransi, terorisme dan lain-lain akibat kurangnya pembinaan secara mendalam oleh pemerintah. Pemerintah kabupaten sulit melakukan pembinaan dan pemberdayaan secara langsung dan intens kepada masyarakat di kecamatan atau desa karena rentang kendali pemerintahan yang panjang.

Sosialisasi dan arahan dari perangkat pemerintah kabupaten, tidak mampu dilaksanakan dengan baik pada saat pemerintah ditingkat bawah tidak 
memiliki anggaran yang cukup, padahal Grindele (1980) menegaskan keberhasilan pelaksanaan kebijakan salah satu ditentukan faktor sumberdaya yang dikerahkan atau menurut Van Mater dukungan sumberdaya manusia dan non manusia. Kebijakan daerah menyangkut pelaksanaan Urusan Pemerintahan Umum sebaiknya ditetapkan secara jelas dan lugas dengan Peraturan Daerah ataupun Peraturan Bupati, demikian pula skema penganggaran dan pembiayaannnya. Manakalah undangundang memerintahkan kepada daerah untuk melaksanakan Urusan Pemerintahan Umum di Daerah dan Bupati telah mendelegasikan beberapa urusan terkait dengan lingkup Urusan Pemerintahan Umum kepada Camat, maka Pemerintah Kabupaten semestinya memberi ruang pada pemerintah kecamatan untuk melaksanakan urusan tersebut dengan baik yang ditunjukan dengan kebijakan pengalokasian anggaran yang memadai bagi pemerintah kecamatan untuk dapat melaksanakan tugas dan fungsinya.

\section{KESIMPULAN}

Akhir dari kegiatan peneliti ini dapat diajukan beberapa kesimpulan sebagai berikut :

I. Urusan Pemerintahan Umum di kecamatan belum dilaksanakan secara optimal oleh Pemerintah Kecamatan Kahayan Tengah.

2. Pelaksanaan Urusan Pemerintahan Umum dilaksanakan sebagai pelaksanaan Urusan Perangkat Pemerintah Daerah Otonom atau sebagai pelaksanaan Urusan Atributif.

3. Bupati Pulang Pisau tidak mendelagasikan secara spesifik Urusan Pemerintahan Umum ke Pemerintah Kecamatan Kahayan Tengah. Beberap urusan yang dilimpahkan atau di delegasikan menyangkut Urusan Bidang Pemerintahan,Pendidikan dan Kesejahteraan, Sosial dan Kesejahteraan Masyarakat, Ekonomi dan Pertambangan, Pertanahan, Perizinan Lain-Lain.

4. Anggaran yang dialokasikan kepada Pemerintah Kecamatan Kahayan Tengah relatif masih sangat minim. Belanja Langsung (Belanja Modal) berkisar antara 400-700 juta selama 3 tahun terakhir. Minimnya alokasi anggaran menyebabkan kurang tajamnya program baik dari segi kuantitas (jumlah) maupun kualitas. Pemerintah Kecamatan Bukit Batu menyusunan anggaran sesuai kapasitas anggaran yang dialokasikan sebagaimana DPA-SKP Kahayan Tengah.

5. Urusan Pemerintahan Umum dilaksanakan langsung oleh Pemerintah Kabupaten melalui instansi teknis seperti Badan Kesbangpol Kabupaten dan Dinas teknis terkait lainnya.

6. Minimnya anggaran Pemerintah Kecamatan sedikit banyak menurunkan kapasitas dan kewibawaan Pemerintah Kecamatan di mata para Kepala Desa dan masyarakat di wilayah Kecamatan Kahayan Tengah.

7. Anggaran kegiatan desa lebih memadai dibandingkan anggaran Pemerintah Kecamatan yang membawahi beberapa desa/kelurahan di wilayah kerjannya.

\section{SARAN-SARAN}

Dari hasil penelitian ini direkomendasikan hal-hal sebagai berikut :

I. Perlu dilakukan evaluasi menyeluruh terhadap pelaksanaan Urusan Pemerintahan Umum di Kecamatan oleh Pemerintah dan pemerintah daerah provinsi, kabupaten/kota baik menyangkut kejelasan tafsir aturan, proses pelaksanaan dan keberhasilan program, mengingat arti penting pelaksanaan Urusan Pemerintahan Umum bagi keberlangsungan kehidupan bernegara dan berbangsa dan eksistensi pelayanan pemerintah kecamatan sebagai garda terdepan pemerintah dalam pelayanan publik setelah pemerintah desa dan kelurahan.

2. Urusan Pemerintahan Umum di kecamatan harus ditetapkan dan diperkuat dengan peraturan bupati sebagai bagian urusan delegatif sebagaimana ketentuan Pasal 25 ayat (4) dan (5) dan bukan sebagai urusan atributif belaka sebagaimana Pasal 
225 ayat (2) Undang-Undang No.23 Tahun 2014 tentang Pemerintahan Daerah.

3. Pelaksanaan Urusan Pemerintahan Umum di kecamatan oleh Camat harus diikuti dengan pembiayaan yang bersumber dari dana APBN bukan hanya bertumpu pada DPA-SKP Kecamatan yang melaksanakan tugas urusan pemerintahan otonom.

4. Pemerintah kabupaten harus melimpahkan pelaksanaan Urusan Pemerintahan Umum di kecamatan dan mengurangi peran sentral Badan Kesatuan Bangsa dan Politik kabupaten/kota.

5. Urusan Pemerintahan Umum yang mampu di laksanakan pemerintah kecamatan harus diserahkan pada pemerintah kecamatan, pemerintah kabupaten bersifat koordinasi, monitoring dan evaluasi.

6. Perlu meningkatkan koordinasi, komunikasi dan integrasi penyelenggaraan Urusan Pemerintahan Umum dikecamatan oleh para pemangku kepentingan.

\section{REFERENSI}

Bungin, Burhan. (2003). Analisis Data Penelitian Kualitatif. PT. Raja Grafindo Persada. Jakarta.

Djaeni, Aries, Enceng, Siti Aisyah (2014). Hubungan Pusat dan Daerah. Universitas Terbuka, Jakarta.

Koontz O Donnel and Weihrich (1980). Pelimpahan Kewenangan Pada Tingkat Pemerintahan di Indonesia. Pustaka Ilmu, Jakarta.

Kertapradja, E. Koswara, Peranan dan Kedudukan Camat dalam Sistem Pemerintahan Negara Kesatuan Republik Indonesia, Makalah disampaikan sebagai bahan Diskusi pada Forum Democratic Reform Support Program (DRSP), 5 November 2007;

Syafie, Inu Kencana (200I). Pengantar IImu Pemerintahan. PT. Raja Grafindo, Jakarta.

Kaho, Josef Riwu. (199I). Prospek Otonomi Daerah di Negara Republik Indonesia, Identifikasi Beberapa Faktor Yang Mempengaruhi Penyelenggaraan. Rajawali Pers, Jakarta.

Moleong, Lexy J. (2006). Metodologi Penelitian Kualitatif. Bandung : Penerbit Rosda.

Sugiono (2008). Metode Penelitian Administrasi. CV. Alfabeta Bandung.

Soekanto (2003). Kepemimpinan Organisasi Publik. CV. Alfabeta Bandung.
Sedarmayanti (2004). Peran Pemerintah dalam Penyelenggaraan Pemerintahan Daerah. PT. Raja Grafindo, Jakarta.

Terry, Goerge. (1960). Pengantar Manajemen dan Aplikasi. Bumi Aksara, Jakarta.

Rasyid, Ryass (2000). Makna Pemerintahan, Tinjauan dari Segi Etika dan Kepemimpinan. PT. Mutiara Sumber Widya, Jakarta.

Winarno, Budi. (20I2). Kebijakan Publk Teori, Proses dan studi Kasus. Jakarta, Penerbit Caps.

Wasistiono, Sadu (2005). Pemerintah Kecamatan Berdasarkan Paradigma Baru. PT. Gramdia, Jakarta.

(2009). Perkembangan Organisasi Kecamatan dari Masa ke Masa. Lembaga Kajian Manajemen Pemerintahan Daerah (LKMPD). Fokusmedia, Bandung.

Wahab, Solichin Abdul. (1997). Analisis Kebijakan Publik, Teori dan Aplikasinya. Malang : PT. Danar Wijaya

(1990). Pengantar Analisis Kebijaksanaan Negara. Jakarta : PT. Rineke Cipta. 